\title{
SUPERENDIVIDAMENTO: Um Problema Individual ou Coletivo?
}

\author{
http://dx.doi.org/10.21527/2176-6622.2020.53.55-68
}

Recebido em: 2/9/2019

Modificações solicitadas em: 20/1/2020

Aceito em: 26/2/2020

\section{Mariana Dionísio de Andrade}

Doutorado em Ciência Política pela Universidade Federal de Pernambuco (PPGCP/UFPE, bolsista Capes). Pesquisadora do Grupo de Pesquisa Epistemologia e Método na Ciência Política Comparada (UFPE). Mestrado em Direito Constitucional pela Universidade de Fortaleza (Bolsista Funcap). Especialização em Direito Processual Civil. Professora da Disciplina Direito Processual Civil e Teoria Geral do Processo no curso de Graduação em Direito e da Pós-Graduação Lato Sensu (Unifor e UNI7). Professora da Pós-Graduação Lato Sensu da Escola Superior da Magistratura do Estado do Ceará (Esmec). Pesquisadora do Multidoor Courthouse System. Formação em Métodos de Pesquisa Quantitativa e Qualitativa pela Universidade Estadual do Rio de Janeiro (Uerj/lesp). Formação em Leadership and Conflict Management pela Stanford University. Foi pesquisadora líder do Projeto Processo Civil e Proteção da Pessoa nas Relações Privadas - Procip (CNPq/Unifor, 2018-2019). Pesquisadora líder do Projeto Pesquisa Empírica em Direito (Probic/ Unifor, 2019-2020). Tem experiência na gestão acadêmica e na docência superior na área de Direito, com ênfase em Direito Processual Civil e Direito Público, atuando principalmente nos seguintes temas: direito processual civil, pesquisa quantitativa e jurimetria, educação jurídica, políticas públicas, accountability. Advogada. http://lattes.cnpq. br/237523808611. http://orcid.org/0000-0001-8698-9371. mariana.dionisio@unifor.br

\section{Eduardo Régis Girão de Castro Pinto}

Doutorando em Direito Constitucional pela Universidade de Fortaleza (2018). Graduação em Direito (1999) e Mestrado em Direito Constitucional (2009) pela Universidade de Fortaleza. Professor de direito civil, na Graduação e na Pós-Graduação Lato Sensu da Universidade de Fortaleza (Unifor). Professor da Pós-Graduação Lato Sensu da Escola Superior da Magistratura do Estado do Ceará (Esmec). Assessor Jurídico da Corregedoria-Geral de Justiça do Estado do Ceará. Coordenador do Projeto Pesquisa Empírica em Direito - Proped (CNPq/Unifor). Tem experiência na área de Direito, com ênfase em Direito Civil-Constitucional, atuando principalmente nos seguintes temas: direito civil e processual civil, direito do consumidor, direitos culturais e direitos fundamentais. http://lattes.cnpq.br/832251757616. http://orcid.org/0000-0001-6949-4940. eduardorg@unifor.br

Beatriz Frota Moreira

Pesquisadora do Projeto Pesquisa Empírica em Direito (Probic/Unifor), vinculado ao curso de Direito da Universidade de Fortaleza (Unifor), sob orientação da professora doutora Mariana Dionísio de Andrade e do professor mestre Eduardo Régis Girão de Castro Pinto. Pesquisadora do Projeto Processo Civil e Proteção da Pessoa nas Relações Privadas - Procip (CNPq/Unifor, 2018-2019). Monitora institucional vinculada à Unifor (Promon/Unifor, 2019). Estagiária institucional da Corregedoria Geral da Justiça do Estado do Ceará (CGJ/CE, 2019). Estagiária Institucional da 3a Câmara de Direito Privado do Tribunal de Justiça do Estado de Ceará. http://lattes.cnpq. br/4737595729280826. https://orcid.org/0000-0002-3692-6572. beatrizfrotamoreira@gmail.com

\section{RESUMO}

O objetivo do presente estudo consiste em responder ao seguinte problema de pesquisa: A falta de tutela do superendividamento no ordenamento jurídico brasileiro possui consequências puramente individuais ou com abrangência social? Para responder a essa pergunta o estudo parte do pressuposto de que o Estado tem o dever de velar pela vida digna dos cidadãos a ele subordinados. Para isso faz-se necessário entender o conceito de superendividamento e suas consequências práticas, assim como é necessário apresentar argumentos voltados à aprovação do Projeto de Lei $n^{\circ}$ 283/2012, que traz uma maior proteção ao endividado e uma vez instituídas essas novas regras é possível atingir um meio de combater e prevenir o fenômeno do superendividamento na sociedade. $O$ método adequado para a abordagem do tema será a reunião da abordagem qualitativa, por meio de revisão de literatura e abordagem quantitativa, por meio de bases de dados secundários, coletados principalmente no Conselho Nacional de Justiça. Conclui-se que a falta de tutela do superendividamento estimula o crescimento do problema a cada ano, o que acarreta consequências não só aos indivíduos endividados, mas à sociedade como um todo.

Palavras-chave: Superendividamento. PL 283/2012. Insolvência civil. Direito do consumidor. Poder judiciário.

\section{OVER INDEBTEDNESS: AN INDIVIDUAL OR SOCIAL PROBLEM?}

\section{ABSTRACT}

The objective of the present study is to answer the following research problem: does not the supervision of super indebtedness in the Brazilian legal system have only individual or social consequences? To answer this question, the study assumes that the State has a duty to ensure a dignified life of the citizens subordinated to it. For this, it is necessary to understand the concept of over-indebtedness and its practical con- 
sequences, as well as to present arguments for approval of PL 283/2012, which brings greater protection to the indebted and once these new rules are implemented it is possible to reach a way to combat and prevent the phenomenon of over-indebtedness in society. The appropriate method for approaching the topic will be the meeting of the qualitative approach, through literature review and quantitative approach, through secondary databases, collected mainly from the National Council of Justice. It's concluded that the lack of protection of super indebtedness stimulates the increase of the problem every year, which has consequences not only to indebted individuals but to society as a whole.

Keywords: Overindebtedness. PL 283/2012. Civil insolvency. Consumer right . Judicial power.

\section{SUMÁRIO}

1 Introdução. 2 Superendividamento: concepção histórica e social. 2.1 Do superendividamento à insolvência civil. 2.20 superendividamento do consumidor. 3 Processo de insolvência. 4 Descrição e análise da base de dados. 5 A aprovação do PL n 283/2012 como mecanismo de prevenção ao superendividamento. 6 Conclusão. 7 Referências.

\section{INTRODUÇÃO}

O objetivo do presente estudo consiste em responder ao seguinte problema de pesquisa: A falta de tutela do superendividamento no ordenamento jurídico brasileiro possui consequências puramente individuais ou com abrangência social? Para responder a essa pergunta faz-se necessário entender alguns elementos essenciais, como o conceito de superendividamento e suas consequências práticas, o conceito de mínimo existencial e a forma de utilização e acesso ao crédito.

Nessa perspectiva, faz-se necessário destacar a existência de uma íntima correlação entre a falta de proteção da pessoa superendividada e a possibilidade de esta pessoa não conseguir manter uma condição mínima de vida (mínimo existencial) e, portanto, ter sua dignidade ferida em decorrência deste fenômeno. Dessa forma, a falta de legislação específica para este problema é um meio de deixar desamparada a população.

Ademais, diversos problemas concorrem para o alastramento do fenômeno em questão, entre eles a educação popular escassa e muitas vezes em níveis inadequados, cerceando o povo de informações necessárias ao controle financeiro e gerenciamento do crédito, além da correlação do consumo com a aparente ascensão social almejada por muitos cidadãos brasileiros, de forma a se incluírem socialmente por meio dos objetos a fim de alcançarem um status social elevado, porém irreal.

Em conformidade com a Constituição Federal de 1988, é dever do Estado zelar pela dignidade da pessoa humana, em todas as suas esferas, além da obrigação de zelar pela proteção do consumidor. A negligência da tutela do superendividamento no ordenamento jurídico brasileiro acarreta um claro desrespeito às normas constitucionais supracitadas, ocasionando problemas econômicos e sociais.

O estudo divide-se em cinco tópicos. O primeiro aborda concepções gerais sobre o fenômeno do superendividamento e suas acepções históricas e sociais, abordando também possíveis falhas na atuação do Estado em diferentes perspectivas e as consequências aos jurisdicionados.

O segundo tópico aborda o processo de insolvência da pessoa física, assim como a classificação doutrinária das formas de insolvência e o modo como o Brasil tutela esta ferramenta em comparativo com demais Estados.

O terceiro item, por sua vez, descreve a análise de dados, pautada em dados secundários retirados principalmente do banco de dados do Conselho Nacional de Justiça (CNJ), em seu programa "Justiça em Números" como fonte de estatísticas do poder Judiciário para divulgar a realidade dos tribunais brasileiros à população a fim de abordar a questão do superendividamento como impulsionador de outros problemas sociais, como a morosidade apresentada no poder Judiciário.

O quarto tópico analisa o Projeto de Lei $n^{\circ} 283 / 2012$, elaborado pelo senador José Sarney (PMDB) em 2015, a fim de disciplinar o crédito ao consumidor, assim como prevenir e tratar o superendividamento. O referido projeto visa, portanto, a não excluir socialmente a pessoa endividada/consumidor e fomentar a prática e concessão do crédito de forma responsável e a atividade de conciliação, abordando as formas de repactuação de crédito, por exemplo, como forma de diminuir o congestionamento do poder Judiciário que já se evidencia atualmente.

A pesquisa possui suporte qualitativo e quantitativo, uma vez que a dúplice metodologia mostra-se importante para conferir veracidade ao conteúdo a ser explicitado. 
$\mathrm{Na}$ abordagem quantitativa utilizou-se o método de pesquisa bibliográfica com vista à revisão literária a fim de explicitar fenômenos históricos e sociais acerca do superendividamento e possibilitar a comparação dos métodos de insolvência utilizados pelo Brasil e demais países.

$\mathrm{Na}$ abordagem quantitativa, por outro lado, utilizou-se diferentes bases de dados secundários objetivando o fortalecimento das inferências feitas ao longo da pesquisa, como dados advindos do Serviço de Proteção ao Crédito e Confederação Nacional de Dirigentes Lojistas (SPC/CNDL), dados do Instituto Brasileiro de Geografia e Estatística (IBGE) e Conselho Nacional de Justiça (CNJ).

O desenvolvimento do presente trabalho objetiva a produção científica para o ambiente acadêmico e tem o propósito de fomentar o debate acerca do problema explicitado, principalmente para as Ciências Jurídicas, a partir uma abordagem original sobre o tema.

\section{SUPERENDIVIDAMENTO: CONCEPÇÃO HISTÓRICA E SOCIAL}

O superendividamento é o fenômeno advindo do modelo social do capitalismo, que no decorrer do século 19 até final do século 20 irradiou-se devido às grandes expansões econômicas ocorridas no período. Dessa forma, o mundo começa a se tornar capitalista e países desenvolvidos passam a ser economias industriais. Tal sistema econômico consolida-se como o principal sistema global e assim continua até os dias atuais (HOBSBAWM, 1988).

É esse o modelo econômico vivenciado por quase o mundo inteiro no século 21 e que influencia e proporciona as pessoas a comprarem, como forma de se autopromover na sociedade, ou seja, fazer do objeto de consumo um meio de inclusão social. Nesse sentido, a motivação do consumo mudou de forma que o desejo passa a se sobrepor à necessidade e a busca pela competência e felicidade está no mercado e nos objetos, não como características pessoais (BAUMAN, 2001).

Essa condição psicológica, criada pela publicidade dos objetos, é aliada com a concessão do crédito para permitir que os consumidores cedam à "estratégia do desejo", como denomina Jean Baudrillard. Dessa forma tais consumidores, já possuindo o desejo de comprar determinados objetos e já encantados pelas propagandas publicitárias, encontram no crédito uma forma de "antecipar o gozo dos objetos no tempo" (BAUDRILLARD, 1997).

Esse desejo pela compra e pelos objetos torna-se ainda mais fácil com as modificações nas relações de consumo do século 21, pois, com o advento da globalização e das compras on-line, os consumidores conseguem ter acesso ao ambiente de compras virtual sem sair da comodidade de suas casas e o Brasil é um dos países em ascensão nesse novo contexto social (MARQUESI; SABO; LÊDO, 2018). Ademais, por vezes, os consumidores ainda conseguem achar preços mais acessíveis que os encontrados em centros comerciais convencionais, como shopping centers e lojas físicas.

O desejo da ascensão social e a errônea ideia, criada e mantida por estratégias publicitárias, da possibilidade de tal ascensão por meio da compra, aliada à facilidade de acesso ao crédito criam um cenário favorável ao fenômeno a ser abordado.

O superendividamento apresenta-se como o início da trajetória da pessoa natural rumo à insolvência civil, e esta pode ser vista como equivalente à falência de pessoas jurídicas (PAULA, 2016), ou seja, torna-se insolvente a pessoa possuidora de mais dívidas que de poder aquisitivo para saldá-las, e essa é a realidade de muitos cidadãos brasileiros. O Serviço de Proteção ao Crédito (BRASIL, 2017) atesta que o número de consumidores com restrição no Cadastro de Pessoas Físicas (CPF) subiu, em julho de $2018,4,31 \%$ em relação ao mesmo mês do ano anterior. Além disso, em relação às dívidas em nome de pessoas físicas a inadimplência avançou 1,47\% no mesmo lapso temporal. Esses dados revelam a forma como o país encerrou o mês de junho: com 63,4 milhões de negativados (BRASIL, 2018d).

O superendividamento não gera consequências somente à pessoa endividada, mas também à sociedade, pois é um fenômeno ligado ao consumo e, consequentemente, à economia. Para solucionar esse problema faz-se necessário reconhecer e entender o que leva tantos cidadãos à insolvência, estabelecendo meios para o retorno das pessoas à vida social e econômica, sendo a principal forma abordada a proteção à pessoa endividada pela legislação, ainda inexistente no Brasil. 


\subsection{Do superendividamento à insolvência civil}

Primeiramente faz-se necessário abordar alguns conceitos quanto ao superendividamento e a forma como este fenômeno crescente tende a levar cada vez mais pessoas à insolvência civil.

O superendividamento ainda não foi abordado pela legislação brasileira, por isso a doutrina consolidou entendimentos sobre o tema com base, principalmente, no Direito comparado francês e norte-americano (PAULA, 2016). Dessa forma, Cláudia Lima Marques conceitua o fenômeno "como a impossibilidade global de o devedor pessoa física, consumidor, leigo e de boa-fé, pagar todas as suas dívidas atuais e futuras de consumo (excluídas as dívidas com o fisco, oriundas de delitos e de alimentos)" (MARQUES; CAVALLAZZI, 2006).

De forma contrária, a insolvência civil encontra-se positivada no ordenamento jurídico, porém traz conceito muito semelhante ao do superendividamento. O artigo 955 do Código Civil Brasileiro (CC) e o artigo 748 do Código de Processo Civil (CPC) de 1973, recepcionado pelo artigo 1.052 do CPC de $2015^{1}$ dispõem que existirá insolvência quando as dívidas excederem a importância dos bens do devedor, ou seja, quando o saldo financeiro do devedor for insuficiente para suprir suas dívidas (BRASIL, 1973, 2015 ).

A diferença entre tais institutos encontra-se na forma de uma pessoa tornar-se superendividada ou insolvente. Para uma pessoa ser denominada como insolvente civil ocorrerá um processo judicial para declarar tal situação, mas para uma pessoa tornar-se superendividada basta que possua mais dívidas do que ativo financeiro para supri-las.

Mesmo existindo dispositivos legais que abordam a insolvência da pessoa natural ainda existe uma insuficiência da legislação na proteção dessas pessoas. Isto ocorre porque a legislação somente formaliza o processo da insolvência e este baseia-se na liquidação de bens da pessoa endividada para efetuar o pagamento a todos os credores ou a quantos for possível. É o que se observa nos artigos 774 e 775 do CPC/73, também recepcionados pelo artigo 1.052 do $\mathrm{CPC} / 15$, os quais regulamentam que, após efetuado o pagamento integral de todos os credores possíveis o devedor ainda estará obrigado pelo saldo, a ser pago pelos bens penhoráveis adquiridos pelo devedor até extinguirem-se todas as suas obrigações (BRASIL, 1973, 2015b).

Nessa perspectiva, nota-se o superendividamento como fenômeno anterior à insolvência civil, portanto um dá causa ao outro. Dessa forma, quando a legislação regula somente o processo posterior, de insolvência, ela deixa clara a preocupação exclusiva com o credor da dívida e deixa desprotegido o devedor endividado, e tal falta de regulamentação acaba acarretando um problema jurídico (NETO; BEZEN, 2017). Isto ocorre porque a legislação existente, regulamentando o processo de insolvência, tenta remediar o problema do superendividamento, que não foi e não está sendo prevenido.

Tal situação acontece porque o endividamento é um fenômeno visto na sociedade como algo passível de sanção, como um erro pessoal e, muitas vezes, inadmissível, uma falha individual perante o credor e a comunidade. Este entendimento pode possibilitar o crescimento do número de endividados e, por consequência, de futuros insolventes.

Esse pensamento é estatisticamente demonstrado por Alexandre Samy Castro em sua pesquisa por meio do favorecimento existente à parte hipersuficiente nos conflitos judiciários. Este autor, ao trabalhar com mais de 40 mil sentenças na área cível na Justiça Estadual do Paraná, chegou à conclusão supramencionada, analisando decisões proferidas em processos nos quais litigam pessoas físicas com pessoas jurídicas, e aquelas são as partes hipossuficientes na relação em análise, litigando com o benefício da Assistência Judiciária Gratuita (AJG) (CASTRO, 2012).

Em ambas as amostras - a primeira com a pessoa física atuando no polo ativo e a segunda com a pessoa física atuando no polo passivo - o resultado mostrou maior probabilidade de a parte hipossuficiente, pessoa física, perder a ação em detrimento da parte hipersuficiente, pessoa jurídica. Nessa perspectiva, ao tratar de

\footnotetext{
Com o advento de uma nova Constituição, ocorre um processo de "filtragem constitucional", em que será averiguado quais normas infraconstitucionais estão de acordo com a nova Constituição e, portanto, poderão permanecer no ordenamento jurídico. Essa integração de normas antigas a normas novas é chamada de "recepção"; é o que ocorre quando o CPC de 2015 mantém, ou seja, recepciona, artigos do CPC de 1973 (BARCELLOS, 2018).
} 
pessoas superendividadas e, por consequência, hipossuficientes, nota-se uma tendência de desfavorecimento ao pobre no âmbito judiciário e tal viés estende-se perfeitamente ao superendividado e ao insolvente (CASTRO, 2012).

Dessa forma, a falta de proteção estatal ao devedor superendividado, além de deixá-lo desamparado perante uma situação de desigualdade contratual, acarreta também situação negativa para o credor, podendo este ficar sem receber aquilo ao qual tem direito. Desse modo, a proteção bilateral torna-se um benefício evidente para ambas as partes da relação jurídica, além da referida proteção ser também mecanismo de controle econômico, o que beneficia a sociedade como um todo e não somente pessoas de forma individual.

\subsection{0 superendividamento do consumidor}

O superendividamento está intimamente ligado às relações consumeristas do século 21, por isso o conceito supracitado de superendividamento por Cláudia Lima Marques expressamente aborda o superendividado como consumidor. Nessa perspectiva tem-se mais um motivo para a eficaz proteção do devedor, pois o consumidor figura, costumeiramente, como parte hipossuficiente da relação. Ademais, é obrigação do Estado promover o mínimo existencial para a vida digna. Dessa forma, a falta de proteção ao superendividado, assim como o próprio processo de insolvência, estão em clara contradição a esse princípio.

Nesse sentido, o fenômeno do superendividamento - e do inadimplemento como um todo - não está relacionado somente ao consumo compulsivo de um indivíduo que não sabe gerenciar suas contas, está também relacionado com a falta de educação e informação da população sobre as relações consumeristas e a forma de gerenciar os gastos, assim como está ligado, no aspecto psicológico, com a aparente ascensão social que os bens trazem aos seus portadores e à forma de inclusão que esse novo status social traz ao indivíduo adquirente do bem.

Os problemas supracitados não estão elencados como os únicos referentes ao problema em questão, mas como os motivos ensejadores do fenômeno, ou seja, é a partir deles que surge a questão central, portanto, devem ser combatidos como meio de prevenção ao alastramento do superendividamento e à futura não reincidência deste na sociedade.

A escassez de informação repercute de forma tão direta no problema do superendividamento que, segundo a pesquisa Inadimplentes no Brasil 2017 Perfil e Comportamento Frente as Dívidas (BRASIL, 2017) "nove em cada dez entrevistados (93,0\%) pertencem às classes C, D e E e 75,3\% dos inadimplentes possui, no máximo, o segundo grau completo". Além disso, muitas pessoas não conseguem gerir sua renda de tal forma que não sabem estipular o tamanho das suas dívidas e seus gastos, como informa a mesma pesquisa (BRASIL, 2017), "o valor médio das dívidas dos entrevistados é de $\mathrm{R} \$ 2.979,54$. Mas $43,5 \%$ dos entrevistados dizem não saber o valor" e segundo aponta indicador do SPC - Brasil e da Confederação Nacional de Dirigentes Lojistas (CNDL), 33\% dos usuários de cartão de crédito não sabem o quanto gastaram no mês de maio de 2018 (BRASIL, 2018c).

Ademais, é fato notório que a falta de educação no Brasil traz uma carência geral no país, incitando inúmeros problemas, todos com a mesma patologia: falta de informação popular. O Brasil, segundo o Instituto Brasileiro de Geografia e Estatística (IBGE, 2018), possuía em 2017, 11,5 milhões de pessoas que ainda não sabem ler ou escrever. Tal montante de pessoas analfabetas, a falta de ensino sobre relações consumeristas nas escolas e a análise dos dados abordados anteriormente permitem inferir a falta de informação como o principal motivo ensejador do superendividamento.

O segundo problema abordado como principal para dar início ao superendividamento é a questão psicológica, de ascender socialmente por meio da aquisição de bens móveis e imóveis, mesmo que de forma aparente. Devido a isso, Jean Baudrillard afirma que o sistema do consumo pauta-se em três pilares, quais sejam, o compromisso - e a vontade popular - pela igualdade, o mito da abundância e o mito de bem-estar, portanto os particulares consomem buscando igualarem-se socialmente para alcançar o bem-estar próprio em sociedade (BAUDRILLARD, 2014). 
Sendo assim, a utilidade real dos produtos não é dimensionada, mas sim a satisfação - muitas vezes meramente momentânea - em possuir aquele determinado objeto. Essa satisfação é motivada exatamente pelo status que os objetos são capazes de proporcionar, mesmo que por período de tempo finito e assim, não se vislumbra no momento da aquisição a utilidade ou destinação do objeto de consumo, tampouco os impactos ambientais e sociais derivados de tal comportamento desenfreado (PORTO; TORRES, 2013).

Esse problema intensifica-se a partir do crédito liberado ao consumidor, porque, se antigamente o consumidor precisaria juntar o dinheiro e posteriormente comprar um bem mais valioso, com o advento do cartão de crédito e dos empréstimos bancários é possível a compra dar-se anteriormente a uma efetiva renda mensal, ou seja, a compra precede o trabalho (BAUDRILLARD, 1997).

Dessa forma, tal compra irá comprometer a renda futura e, possivelmente, a subsistência das pessoas que optarem por esse tipo de transação sem saber gerir todos os bônus e os ônus que esta proporciona. Devido a isso, a sociedade do crédito remonta uma tipicamente feudal, "a de uma fração de trabalho devida antecipadamente ao senhor, ao trabalho escravo" (BAUDRILLARD, 1997).

Por isso, a autora Fabiana Andréa Pellegrino, afirma que o superendividamento é também consequência da democratização do crédito, que teve início nos séculos 19 e 20 devido, prioritariamente, às vendas parceladas. Com o advento da massificação do crédito, este estimulou o mercado consumerista, tornando-se o impulsionador da economia de consumo, porém o crédito também veio a ser um impulsionador da cultura do endividamento, deixando este de ser um problema individual e dando lugar ao fenômeno do superendividamento como um problema jurídico e social (PELLEGRINO, 2014).

Com o amplo estímulo ao crédito, anteriormente mencionado, uma das maiores buscas das instituições financeiras foram os aposentados, pois o Instituto Nacional do Seguro Social (INSS) efetua o desconto direto da prestação do benefício recebido pelo aposentado ou pensionista. A facilidade do crédito para todos, porém, inclusive para aqueles com restrições creditícias, ensejou a adesão desenfreada ao crédito, atingindo a marca de mais de 5 milhões de aposentados utilizando-se deste benefício em abril de 2006, atingindo valor superior a 13 bilhões de reais (BERTONCELLO; LIMA, 2007).

Os efeitos do acesso ao crédito, entretanto, aliados à falta de regime legal específico ao superendividamento, gerou uma alta busca pelo poder Judiciário em ações de revisão contratual, objetivando a limitação de juros exorbitantes, entre outros pedidos recorrentes. Somente em 2004 tais medidas judiciais chegaram a quase 10.000 demandas (BERTONCELLO; LIMA, 2007 ), contribuindo para o congestionamento dos órgãos judiciais.

Esse congestionamento, em 2004, chegou a 96,4\% no Ceará, a 75,8\% no Estado de São Paulo e a 18,4\%, um dos menores percentuais, no Estado do Rio de Janeiro (BRASIL, 2004), porém esses números continuam preocupantes com o decorrer dos anos. Em 2017 o Tribunal de Justiça (TJ) do Ceará registrou 75,2\% em taxa de congestionamento, enquanto o TJSP registrou $77,6 \%$ e o TJRJ $80,1 \%$ (CNJ, 2018). Mais uma vez um problema inicialmente visto como individual torna-se social, atingindo de forma prejudicial a sociedade como um todo.

O objetivo inicial, portanto, de se inserir na sociedade por meio dos bens de consumo irá, posteriormente, impedir o indivíduo de continuar tal ascensão social aparente e gerará problemas a sua própria sobrevivência e a sua própria dignidade, pois a pessoa não conseguirá mais adquirir bens, possuirá dívidas dentro do mercado de crédito e, possivelmente, estará enfrentando um litígio judicial, além de não possuir renda suficiente para seu sustento básico, sendo assim excluída do mercado de consumo e, consequentemente, da vida social.

Ademais, é dever do Estado, previsto constitucionalmente, a defesa do Consumidor (artigo $5^{\circ}, \mathrm{XXXII,}$ CF), e esta não está sendo provida de forma adequada à população, pois apesar da existência do Código de Defesa do Consumidor (CDC) objetivando a proteção desses indivíduos, ele não é completo o suficiente para alcançar todas as alterações sociais ocorridas desde sua criação, no ano de 1990, até os dias atuais, como a facilidade de acesso ao crédito (NETO; BEZEN, 2017; BRASIL, 1988).

Essa falta de proteção atual e específica permitiu o crescimento e alastramento em massa de superendividados na sociedade e, consequentemente, o aumento proporcional no número de insolventes civis. 


\section{PROCESSO DE INSOLVÊNCIA}

A pesquisa qualitativa funda-se na revisão bibliográfica e no aprofundamento teórico dos temas que estão sendo desenvolvidos. Essa metodologia de pesquisa, apesar de importante, pode, não raras vezes, tornar-se demasiadamente abstrata por trabalhar somente com a dialética (ANDRADE, 2018).

Faz-se interessante mesclar com o método qualitativo uma abordagem quantitativa, a fim de trazer para a pesquisa uma dimensão mais concreta do problema ao utilizar dados e mensurações numéricas (ANDRADE, 2018). Nesta pesquisa foram utilizados dados secundários, ou seja, já existentes e disponibilizados por diversas instituições, tais como os do Serviço de Proteção ao Crédito e Confederação Nacional de Dirigentes Lojistas (SPC/CNDL), dados do Instituto Brasileiro de Geografia e Estatística (IBGE) e Conselho Nacional de Justiça (CNJ).

Para as pessoas jurídicas, existe regulamentação específica no processo de falência, disposto na Lei $\mathrm{n}^{\circ}$ 11.101/05, existente para objetivar “(...) a preservação da empresa juntamente com seus ativos e recursos produtivos, a valorização de sua função social e sua reintegração ao mercado e o estímulo à atividade econômica" (PAULA, 2016, p. 2).

Em contrapartida, quando se trata da "falência" de pessoas naturais estas estão desprotegidas, não possuindo lei que busque a preservação da dignidade pessoal no processo de insolvência nem a reintegração da pessoa ao mercado econômico.

A insolvência civil pode resultar de fato alheio à vontade do agente e inesperado. É o chamado de superendividamento passivo, ou pode ocorrer por falta de um adequado gerenciamento de finanças, chamado superendividamento ativo. $O$ superendividamento e a insolvência civil não se confundem, porém estão intimamente ligados como supramencionado: o superendividamento pode ser uma etapa anterior ao processo de insolvência, por isso as causas que levam à insolvência também podem ser chamadas, por analogia, como passiva e ativa, da mesma forma que a doutrina classifica o endividamento excessivo.

No processo em questão o devedor superendividado irá perder todos os seus bens penhoráveis, presentes e futuros, no processo de insolvência.

O artigo 833 do Código de Processo Civil (CPC) de 2015 estipula os bens impenhoráveis em seus incisos I a XII, ou seja, não são poucos os bens que não poderão ser utilizados para o pagamento das dívidas, portanto faz-se mais interessante ao credor a recuperação financeira do devedor, para este, posteriormente, honrar suas dívidas (BRAGA; COSTA, 2017; BRASIL, 2015 ).

O processo de insolvência existente no Brasil já é considerado uma maneira ultrapassada de tratar o referido problema em relação aos demais países e ao Direito comparado. É um modelo classificado como conservador por Rafael Efrat, pois tutela somente o direito do credor e trata o endividamento como um desvio de conduta, como anteriormente mencionado. Além disso, esse processo onera excessivamente o devedor e falha em proporcionar benefícios ao credor, ficando por esse motivo ultrapassado e ineficiente, além de ser maléfico tanto para o indivíduo quanto para o mercado de consumo (EFRAT, 2002).

Outros dois modelos amplamente utilizados no mundo são o modelo liberal, principalmente nos Estados Unidos, e o modelo social, especialmente na Europa. Esses modelos diferem-se, pois o objetivo do modelo liberal é servir de seguro para os riscos advindos do crédito, proporcionando de maneira mais rápida e fácil o perdão das dívidas existentes e o retorno do indivíduo ao mercado de consumo (PALHARES, 2010; EFRAT, 2002).

Em contrapartida, o modelo social trata o problema como "fonte de exclusão social e de desrespeito aos direitos fundamentais", trabalhando, portanto, em processos mais complexos e demorados para solucionar o superendividamento, focando na reeducação dos indivíduos e, portanto, na prevenção do problema no futuro (PALHARES, 2010; ARAÚJO; BRITO, 2017).

Cinara Palhares, ao abordar os modelos de tutelar o problema do superendividamento no Direito comparado, afirma ainda que o mais compatível com o ordenamento jurídico brasileiro é o modelo social, tendo em vista a larga proteção aos direitos fundamentais trazidos pela Constituição Federal de 1988, principalmente em seu artigo 5o (BRASIL, 1988; ARAÚJO; BRITO, 2017). 
O determinado modelo coaduna ainda com o princípio do mínimo existencial, existente para revelar a obrigação do Estado em satisfazer direitos em um nível mínimo de condições compatíveis com a dignidade humana, também prevista na Constituição Federal de $1988 \mathrm{em}$ seu artigo 1 $^{\circ}$, inciso III (BRASIL, 1988 )

Art. 1ㅇ A República Federativa do Brasil, formada pela união indissolúvel dos Estados e Municípios e do Distrito Federal, constitui-se em Estado Democrático de Direito e tem como fundamentos:

III - a dignidade da pessoa humana;

Com base no abordado e na supracitada norma constitucional, percebe-se que educar a população para estabelecer um consumo consciente e para entender, efetivamente, as oportunidades de crédito disponibilizadas no mercado é a forma mais efetiva de prevenir o superendividamento, tanto o passivo quanto o ativo. Além disso, concede às pessoas uma forma de recuperação do inadimplemento, garantindo o mínimo existencial, que pode ser mensurado de acordo com o artigo $7^{\circ}$, inciso IV, CF/88 (BRASIL, 1988 )

IV - salário mínimo, fixado em lei, nacionalmente unificado, capaz de atender às suas necessidades vitais básicas e às de sua família com moradia, alimentação, educação, saúde, lazer, vestuário, higiene, transporte e previdência social, com reajustes periódicos que lhe preservem o poder aquisitivo, sendo vedada sua vinculação para qualquer fim;

Desse modo, impede-se que o inadimplemento se torne um ciclo, em que as pessoas inseridas, ao verem seus bens retirados de si e sua renda insuficiente para suprir a dívida e garantir a subsistência de sua família, não consigam mais se desvencilhar de tais encargos, voltar ao mercado de consumo e nem satisfazer seus credores.

Essa volta ao mercado de consumo é a primeira meta do Projeto de Lei $\mathrm{N}^{\circ} 283 / 2012$, elaborado com a finalidade de dar auxílio às pessoas que dele necessitam para inseri-las novamente na vida em sociedade. Como objetivo final, o projeto busca eliminar o problema do superendividamento e impedir que este volte a ocasionar problemas sociais.

Já está clara a noção do superendividamento e da insolvência civil como problemas sociais, por serem motivadores de diversos outros problemas, como os econômicos e judiciais. Dessa forma, este estudo propõe-se a oferecer evidências ao que está sendo apresentado, por meio de dados secundários, ou seja, já existentes em diversas plataformas, a fim de embasar a existência e a gravidade dos problemas em foco.

\section{DESCRIÇÃO E ANÁLISE DA BASE DE DADOS}

Como anteriormente explicitado, existe uma intrínseca relação entre o aumento do superendividamento e da insolvência civil com o aumento dos processos iniciados no Judiciário em relação a ações de revisão de dívidas e rescisão contratual, por exemplo.

Devido a essa relação, faz-se necessário mostrar quanto o problema do superendividamento interfere no Judiciário brasileiro, revelando a contribuição de um problema (superendividamento e insolvência civil) para o agravamento de outro (aumento de demandas no Judiciário) e em grandes proporções, evidenciando, mais uma vez, o superendividamento como um problema coletivo e social, tendo a necessidade de ser devidamente tratado pelo Estado.

Primeiramente, a base de dados do Conselho Nacional de Justiça (CNJ) ofertados por meio do programa "Justiça em Números" tem como objetivo servir de fonte para as estatísticas do poder Judiciário e divulgar a realidade dos tribunais brasileiros à população.

Dessa forma, podemos extrair os principais assuntos demandados em 2017, do último relatório divulgado pelo programa. Tal relatório revela que na Justiça Estadual os assuntos que ocupam o primeiro e o segundo lugares entre os mais demandados são, respectivamente, a área de Direito Civil, especificamente em relação a obrigações e espécies contratuais, e a área de Direito do Consumidor, especificamente em relação à responsabilidade do fornecedor e indenizações por dano moral.

A área de Direito Civil, portanto, concentra 3,83\% de todas as demandas, totalizando 1.944 .996 (um milhão novecentos e quarenta e quatro mil novecentos e noventa e seis) demandas e a área de Direito do Consumidor concentra 3,46\% das demandas, totalizando 1.760 .905 (um milhão setecentos e sessenta mil novecentos e cinco) demandas. 
Já nos principais assuntos mais demandados no $2^{\circ}$ grau, também em 2017, na Justiça Estadual, o primeiro lugar continua ocupado pela área de Direito Civil, em relação às obrigações e espécies contratuais, e a área de Direito do Consumidor fica em terceiro lugar, com diferença de somente 0,01\% para o segundo lugar, especificamente em relação a contratos de consumo e contratos bancários.

Desse modo, a área de Direito Civil concentra 5,94\% das demandas na Segunda Instância, totalizando 562.660 (quinhentos e sessenta e dois mil seiscentos e sessenta) processos, e a área de Direito do Consumidor concentra 2,69\% das demandas no segundo grau, totalizando 254.530 (duzentos e cinquenta e quatro mil quinhentos e trinta) processos.

Gráfico 1 - Quantidade de ações judiciais por instância

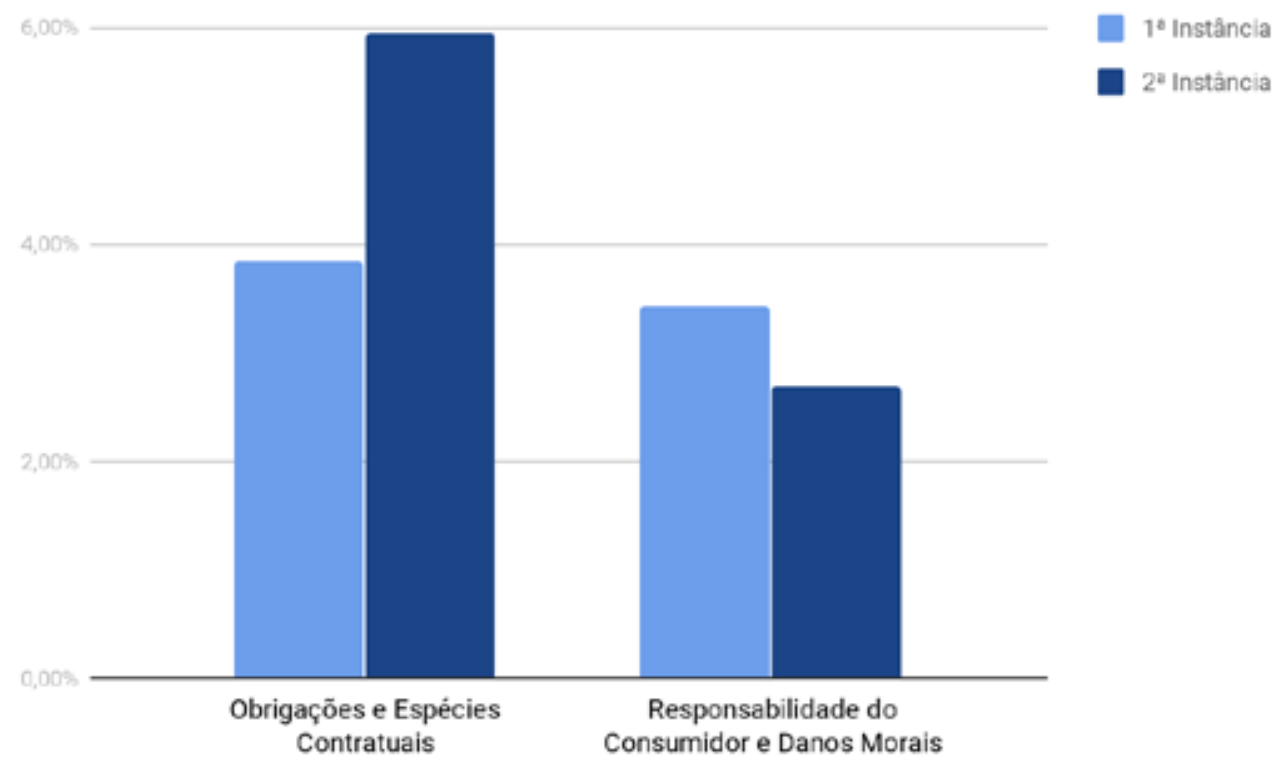

Fonte: Relatório Justiça em números, Conselho Nacional de Justiça - CNJ, 2017. Elaboração própria.

Desses dados extrai-se que grande parte do congestionamento judicial evidenciado na Justiça Estadual é proveniente de problemas como o superendividamento, pois ao tratar demandas judiciais sobre direito das obrigações e espécies contratuais, estarão presentes problemas como inadimplemento de obrigações, como a falta ou o atraso no pagamento ou a execução deste fora dos parâmetros acertados.

Demandas relativas ao Direito do Consumidor também envolvem áreas estritamente ligadas ao superendividamento, principalmente quando são abordados os contratos de consumo e bancários, pois, não raras vezes, têm como objeto do litígio as altas taxas de juros cobradas, fator que corrobora o crescimento das taxas de superendividados.

Ademais, em coleta de dados secundários, a base do Serasa Experian revela o aumento na gravidade do problema ao longo dos anos, pois em agosto de 2017 era de 60,4 milhões o número de consumidores inadimplentes, já em agosto de 2018 esse número subiu para 61,5 milhões e em novembro do mesmo ano já atingia a marca de 62,4 milhões de consumidores inadimplentes, sem dados para dezembro/2018. Nota-se a gravidade do problema aumentando ao longo do tempo e, por isso, necessita-se de urgente e eficaz solução estatal.

Solução esta que o Projeto de Lei no 283/2012 traz com satisfatório detalhamento e real possibilidade de mudança para o problema do superendividamento no Brasil, como será explicitado mais adiante.

\section{A APROVAÇÃO DO PL N² 283/2012 COMO MECANISMO DE PREVENÇÃO AO SUPERENDIVIDAMENTO}

O referido projeto foi elaborado pelo senador José Sarney (PMDB), portanto sua tramitação começou no Senado Federal, foi aprovado pelo plenário e posteriormente remetido à Câmara dos Deputados, no dia 4/11/2015 (BRASIL, 2015a). 
O responsável por colocar os Projetos de Lei (PL) em pauta é o presidente da Câmara ou do Senado, que o fazem de forma totalmente discricionária, pois não existe lei determinando uma ordem de pauta ou qualquer critério preestabelecido.

Assim entendido, apesar de aprovado na primeira casa legislativa não há previsão para a votação do $\mathrm{PL}$ 283/12, agora enumerado PL 3.515/2015, na Câmara dos Deputados. Isso ocorre porque não existe punição ou regra que vede esse tipo de ato. Além disso, se for rejeitado pela casa revisora, o Projeto de Lei será arquivado e só poderá ser objeto de nova deliberação na próxima Sessão Legislativa, ou seja, no ano seguinte (BARCELLOS, 2018, p. 293).

O Projeto de Lei anteriormente explicitado encaixa-se como a espécie normativa de Lei Ordinária, pois apesar de a Constituição positivar a necessidade da Defesa do Consumidor em seu artigo 170, inciso V, esta não dispõe expressamente a necessidade da utilização de espécie normativa diferenciada para tratar de assuntos relativos à ordem consumerista, como se vê adiante (BARCELLOS, 2018; BRASIL, 1988 ):

Art. 170. A ordem econômica, fundada na valorização do trabalho humano e na livre iniciativa, tem por fim assegurar a todos existência digna, conforme os ditames da justiça social, observados os seguintes princípios $\mathrm{V}$ - defesa do consumidor;

Esse tipo de espécie normativa, em regra, será aprovada por maioria simples, registrada a presença da maioria absoluta dos parlamentares da Casa Legislativa, como dispõe o artigo 47 da Constituição da República Federativa do Brasil de 1988 (BARCELLOS, 2018; BRASIL, 1988).

Para a efetiva instituição de tal espécie normativa no ordenamento jurídico, faz-se necessário que a lei percorra o processo legislativo estabelecido pela Constituição de 1988, seguindo procedimento determinado, que será sucintamente explanado, e segue etapas pré-ordenadas de iniciativa legislativa, emendas, votação, sanção e veto e promulgação e publicação (BULOS, 2018).

O Projeto de Lei foi elaborado por meio de iniciativa geral do Senado Federal, de acordo com o artigo 61 da Constituição Federal de 1988, portanto extraordinariamente o Senado Federal será a Casa Iniciadora neste Processo Legislativo. Após proposto o Projeto de Lei, este deverá ser enviado a até três comissões temáticas (escolhidas de acordo com o tema abordado no PL), que emitirão parecer sobre o Projeto analisado, porém sem vincular o voto dos demais membros da Casa, e à Comissão de Constituição e Justiça (CCJ), responsável por averiguar a constitucionalidade do Projeto de Lei; posteriormente deve passar pela votação na Casa Iniciadora e, se aprovado, é enviado à Casa Revisora (no caso, a Câmara dos Deputados) para averiguação (BARCELLOS, 2018; BRASIL, 1988 ).

Ao chegar à Câmara dos Deputados o PL passará novamente por três comissões temáticas e pela CCJ, com a mesma finalidade, e então poderá seguir dois caminhos: caso o Projeto seja aprovado na íntegra, ou seja, sem alterações, seguirá para aprovação ou veto presidencial, porém, caso seja aprovado com alterações elaboradas pela Casa Revisora o PL deve retornar à Casa Iniciadora que decidirá, mediante nova votação, se as alterações serão mantidas ou vetadas e então o PL seguirá para a sanção ou veto presidencial com as alterações ou com o texto original, dependendo do resultado da votação.

Na etapa de veto presidencial o presidente da República poderá aprovar, ou seja, sancionar, o PL e deverá promulgá-lo e publicá-lo, porém, caso o presidente vete o Projeto de Lei este retornará ao Congresso Nacio-

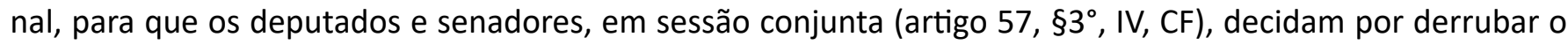
veto presidencial e nesse caso o PL será normalmente publicado e promulgado, ou manter o veto presidencial e arquivar o Projeto (BRASIL, 1988 ).

O Projeto de Lei em estudo ao chegar na Câmara dos Deputados recebeu o $n^{\circ}$ 3.515/2015 e foi encaminhado para as comissões de Direito do Consumidor, de Finanças e Tributação (de acordo com o artigo 54 do Regimento Interno da Câmara dos Deputados) e para a Comissão de Constituição e Justiça no dia 10 de novembro de 2015 e a última movimentação legislativa no projeto ocorreu no dia 7 de dezembro de 2018. Apesar de o projeto 3.515/2015, ou 283/2012 estar em tramitação há três anos, somente na Câmara dos Deputados, ele tramita em regime de prioridade (BRASIL, 2018b).

O Projeto de Lei em questão versa sobre a disciplina do crédito ao consumidor, assim como sobre a prevenção e o tratamento do superendividamento, tema já vastamente exposto. 
O referido Projeto começa acrescentando ao artigo $4^{\circ}$ do CDC o inciso $X$, buscando desconstruir a visão social de que o inadimplemento não deve ser tutelado pelo Direito. Apesar de não ser mais a visão preponderante juridicamente, ainda está muito presente no pensamento social e ainda é o que a legislação vigente apresenta atualmente, portanto trata-se de uma modificação no estilo de tratamento brasileiro acerca do problema da insolvência civil e o início da solução para o problema do superendividamento (BRASIL, 1990).

Art. 4음

$\mathrm{X}$ - prevenção e tratamento do superendividamento como forma de evitar a exclusão social do consumidor (NR).

Ao prezar por "evitar a exclusão social do consumidor", o legislador não visa somente ao benefício individual do superendividado, mas ao benefício coletivo da movimentação da economia do país, beneficiando empregados e empregadores.

Mais um meio eficaz no tratamento da inadimplência social é modificar as relações de crédito existentes atualmente no Brasil, porque, apesar de o acesso ao crédito ser de extrema importância no cenário econômico, o binômio consumo/crédito é extremamente instável, por isso quando muitas pessoas entram no ciclo do superendividamento "uma crise na sociedade é criada, as taxas de inadimplemento sobem, sobem os juros, os preços, a insolvência, cai a confiança, o consumo, desacelera-se a economia...uma reação em cadeia..." (MARQUES; LIMA; BERTONCELLO, 2010, p. 19).

Esse cenário é mais gravoso no Brasil, pois além de o país não possuir legislação específica sobre o tema, como leis de combate à usura dos bancos e financeiras (França) e leis sobre crédito ao consumidor e concessão responsável do crédito a pessoas físicas (27 países da União Europeia), o Brasil ainda é o país "onde os juros são altíssimos, temos o maior spread (lucro do banco) do mundo e as dívidas multiplicam de valores em pouco tempo" (BRASIL, 2010 , p. 19). Nesse sentido, o Projeto de Lei $n^{\circ} 283 / 12$ vem adicionar ao artigo 6응 do CDC , como direito básico do consumidor (BRASIL, 1990):

XI - a garantia de práticas de crédito responsável, de educação financeira, de prevenção e tratamento das situações de superendividamento, preservando o mínimo existencial, por meio da revisão e repactuação da dívida, entre outras medidas;

E disciplina maiores garantias de proteção ao crédito aos idosos, acrescentando ao artigo 96 do estatuto do idoso (BRASIL, 2003):

Art. 96.

§3 Não constitui crime a negativa de crédito motivada por superendividamento do idoso. (NR).

Tal dispositivo é um importante avanço para prevenção do superendividamento do idoso, pois são pessoas naturalmente mais fragilizadas e foram, e ainda são, grandes alvos da concessão de crédito bancário. Como visto anteriormente, em 2006 o número de aposentados utilizando o recurso de crédito foi de aproximadamente 5 milhões.

Além das novas modificações apresentadas, o PL em questão tenta introduzir dois novos capítulos ao Código de Defesa do Consumidor, intitulados "Da Prevenção e do Tratamento ao Superendividamento" e "Da Conciliação no Superendividamento".

O primeiro visa à prevenção do superendividamento, dispondo principalmente sobre o crédito responsável, a educação financeira, o fornecimento e oferta de crédito, o modo de pagamento das dívidas, o direito de arrependimento e as condutas dos fornecedores de crédito.

O segundo capítulo, por sua vez, dispõe sobre os meios para retirar os consumidores da situação de superendividamento, abordando, em síntese, a instauração do processo de repactuação de dívidas, ou caso este seja falho, a instauração do processo de superendividamento para a revisão dos contratos e repactuação das dívidas e atribui a competência da fase conciliatória e preventiva da repactuação aos órgãos públicos de defesa ao consumidor.

Importante ressaltar que, apesar de boa parte do PL dispor sobre meios de assegurar o consumidor, ele não tem como objetivo o prejuízo das empresas, fato expressamente previsto no proposto artigo $104-\mathrm{B}, \S 3^{\circ}$ : 
§3으 O plano judicial compulsório assegurará aos credores, no mínimo, o valor do principal devido corrigido monetariamente por índices oficiais de preço, e preverá a liquidação total da dívida em, no máximo, cinco anos, sendo a primeira parcela devida no prazo máximo de cento e oitenta dias, contados da sua homologação judicial, e o restante do saldo devido mensalmente em parcelas iguais e sucessivas.

Constata-se, portanto, que as ideias trazidas pelo PL n 283/2012 são de importância e relevância para o ordenamento jurídico brasileiro, pois influenciará amenizando a situação de inúmeros brasileiros de forma individual e de forma coletiva, por meio da melhoria na economia devido à regularização da situação do endividamento e consequentemente impedindo a inadimplência.

\section{CONCLUSÃO}

Respondendo ao problema de pesquisa e a partir dos dados explicitados verifica-se que o problema do superendividamento traz consequências sociais em diversos âmbitos. Na esfera do poder Judiciário existe uma íntima correlação entre a elevada quantidade de demandas e os problemas derivados de concessões de crédito e relações consumeristas, assim como na esfera social o superendividamento leva as pessoas à exclusão social ocasionando um impacto direto na economia.

Ter uma população com um alto nível de escolaridade e informada sobre os principais assuntos da vida social e econômica é essencial para o crescimento de uma nação, por isso as soluções para todo problema sempre perpassam pela escassez de escolaridade que a população brasileira apresenta.

Dessa forma, os principais meios encontrados para solução e prevenção do superendividamento são a educação da população sobre o assunto, começando a partir do ensino básico, a fim de permitir que as pessoas em geral saibam como gerenciar contas e poupar dinheiro e entendam a importância de tais práticas, assim como a regulamentação da concessão de créditos ao consumo, não permitindo que as empresas se utilizem de pessoas necessitadas e vulneráveis para difundir o mercado do crédito sem tratar dos posteriores malefícios que este pode trazer.

Não se defende aqui a extinção do crédito à população, mas sim uma concessão mais consciente, que não coloque em dificuldades as pessoas que não conseguem medir os ônus e os bônus do crédito e o risco do inadimplemento.

Além disso, defende-se a introdução de um processo específico ao superendividamento, previsto em lei, conferindo uma efetiva tutela, proteção e solução a este problema social, assim como se defende a prática do princípio do mínimo existencial para resguardar uma condição de vida adequada às pessoas que enfrentam o superendividamento e tentam solucioná-lo.

Como já foi abordado, tratar a insolvência meramente com a liquidação e divisão dos bens existentes e penhoráveis é uma medida ineficaz e ultrapassada para a resolução do problema. Devem ser criadas maneiras de permitir que o insolvente ou o superendividado pague suas dívidas de maneira que não o exclua de uma vida social e comercial e que garanta um patamar de vida aceitável enquanto honra com suas obrigações.

Dessa forma, garantir à população meios de sair da condição de endividamento excessivo e voltar ao mercado de consumo beneficia não só o indivíduo e sua família, que poderão ter sua situação financeira estabilizada novamente, mas também a economia no geral, pois as pessoas voltarão a comprar, gerando aumento de confiança na economia, maior circulação de mercadorias e eventualmente uma maior criação de empregos.

Além de melhorar de forma geral o sistema econômico do país, a solução a longo prazo tanto do superendividamento quanto da insolvência traz um grande benefício também ao quadro do Judiciário como um todo, melhorando principalmente o problema de morosidade existente em suas diversas instâncias. Isto porque o sistema econômico e o sistema judiciário são dois âmbitos muito afetados pelo problema do superendividamento, que está intimamente ligado com a concessão de créditos e a instauração de novas demandas judiciais.

Esse estudo oferece como respostas de médio alcance, principalmente, tornar a população consciente para entender, efetivamente, os efeitos do superendividamento na sociedade, assim como para entender a estrutura das relações de crédito e proporcionar uma imediata extinção das relações de crédito inconscientes. 
A longo prazo, faz-se necessária a introdução de disciplina(s) referente(s) ao estudo das relações consumeristas na grade curricular dos estudantes brasileiros, assim como a aprovação do PL 283/2012 que regula as condições mais importantes para tirar o país de uma situação de grande inadimplência e colocá-lo estabilizado segundo o binômio consumo/crédito.

Conhecer a realidade dos problemas e entender seus efeitos negativos a partir de estatísticas, podendo quantificar, de forma aproximada, a extensão dos danos, pode ser um caminho eficaz de transformação e meIhoria.

Analisar os principais transtornos geradores do problema principal e sua incidência indireta em outras áreas, com perspectivas inovadoras, permite uma melhor visualização e entendimento do problema, ampliando a capacidade de resolução ou ao menos sua melhoria.

\section{REFERÊNCIAS}

ANDRADE, Mariana Dionísio de. A utilização do Sistema R-Studio e a Jurimetria como ferramentas complementares à pesquisa jurídica. Quaestio luris, Rio de Janeiro, v. 11, n. 2, 2018. Disponível em: https://www.e-publicacoes.uerj.br/index.php/quaestioiuris/article/view/29221/24047. Acesso em: 29 mar. 2019.

ARAÚJO, Fábio José de Oliveira; BRITO, Rodrigo Toscana de. Contratos, superendividamento e a proteção dos consumidores na atividade econômica. Direito e Desenvolvimento, João Pessoa, v. 5, n. 9, p. 165-204, jun. 2017. Disponível em: https://periodicos.unipe.br/index.php/direitoedesenvolvimento/article/view/250/232. Acesso em: 11 mar. 2019.

BARCELLOS, Ana Paula. Curso de Direito Constitucional. Rio de Janeiro: Forense, 2018.

BAUDRILLARD, Jean. A sociedade de consumo. 2. ed. Lisboa: Edições 70, 2014.

BAUDRILLARD, Jean. O sistema dos objetos. 3. ed. São Paulo: Perspectiva, 1997. 230p.

BAUMAN, Zygmunt. Modernidade líquida. Rio de Janeiro: Editora Zahar, 2001. Disponível em: https://integrada.minhabiblioteca.com.br/\#/books/9788537807729/cfi/6/28!/4/4/2@0:39.1. Acesso em: 18 fev. 2019.

BERTONCELLO, Káren Rick Danilevicz; LIMA, Clarissa Costa de. Adesão ao projeto conciliar é legal - CNJ, projeto-piloto: "tratamento das situações de superendividamento do consumidor. Tribunal de Justiça do Rio Grande do Sul. Rio Grande do Sul. 2006. Disponível em: http://www.tjrs.jus.br/export/processos/conciliacao/doc/projeto_superendividamento.pdf. Acesso em: 22 jan. 2020.

BERTONCELLO, Karen Rick Danilevicz; LIMA, Clarissa Costa de. Adesão ao projeto conciliar é legal. CNJ. Projeto piloto: tratamento das situações de superendividamento do consumidor. Revista de Direito do Consumidor, São Paulo, n. 63, p. 173-201, jul./set. 2007.

BRAGA, Letícia Góes; COSTA, Vanessa Silva Barbosa da. Análise da necessidade de regulamentação do superendividamento da pessoa natural. Revista Acadêmica Clóvis Beviláqua, Fortaleza, v. 4, n. 1, p. 49-58, jan./jun. 2017. Semestral. Disponível em: http://www.ppgdireito.ufc.br/public_html/images/HELOISA/REVISTA\%20ACADMICA\%20CLVIS\%20BEVILQUA\%20VOLUME\%20 4\%20NMERO\%201.pdf\#page=50. Acesso em: 20 ago. 2018.

BRASIL. Constituição (1988). Constituição da República Federativa do Brasil. Brasília, DF, Senado, 1988.

BRASIL. Lei n. 8.078 de 11 de setembro de 1990. Código de Proteção e Defesa do Consumidor. Brasília, DF, Senado, 1990.

BRASIL. Câmara dos Deputados. Projeto de Lei $n^{\circ}$ 3515/2015. 2015a. Disponível em: http://www.camara.gov.br/proposicoesWeb/fichadetramitacao?idProposicao=2052490. Acesso em: 12 jan. 2019.

BRASIL. Conselho Nacional de Justiça - CNJ. Disponível em: http://www.cnj.jus.br/images/programas/justica-em-numeros/justica_numeros_2004.pdf. Acesso em: 27 dez. 2018a.

BRASIL. Conselho Nacional de Justiça - CNJ. Disponível em: http://www.cnj.jus.br/files/conteudo/arquivo/2018/09/8d9faee7812d35a58cee3d92d2df2f25.pdf. Acesso em: 8 jan. 2019a.

BRASIL. Escola Nacional de Defesa do Consumidor - ENDC. Prevenção e tratamento do superendividamento: caderno de investigações científicas. Vol. 1. Disponível em: https://www.justica.gov.br/seus-direitos/consumidor/Anexos/manual-tratamento-do-super\%20endividamento.pdf. Acesso em: 22 jan. 2020.

BRASIL. Instituto Brasileiro de Geografia e Estatística - IBGE. 2012a. Disponível em: https://agenciadenoticias.ibge.gov.br/ agencia-noticias/2012-agencia-de-noticias/noticias/21255-analfabetismo-cai-em-2017-mas-segue-acima-da-meta-para-2015. html. Acesso em: 14 ago. 2018.

BRASIL. Senado Federal. Código Civil. Disponível em: http://www.planalto.gov.br/ccivil_03/leis/2002/I10406.htm. Acesso em: 13 jan. 2019b.

BRASIL. Senado Federal. Código de Defesa do Consumidor. Disponível em: http://www.planalto.gov.br/ccivil_03/Leis/ L8078compilado.htm. Acesso em: 14 jan. 2019c. 
BRASIL. Senado Federal. Código de Processo Civil. 1973. Disponível em: http://www.planalto.gov.br/ccivil_03/leis/L5869impressao.htm. Acesso em: 13 jan. 2019.

BRASIL. Senado Federal. Código de Processo Civil. 2015b. Disponível em: http://www.planalto.gov.br/ccivil_03/_Ato20152018/2015/Lei/L13105.htm. Acesso em: 13 jan. 2019.

BRASIL. Senado Federal. Constituição Federal. Disponível em: http://www.planalto.gov.br/ccivil_03/Constituicao/Constituicao. htm. Acesso em: 14 jan. 2019d.

BRASIL. Senado Federal. Disponível em: https://www25.senado.leg.br/web/atividade/materias/-/materia/106773. Acesso em: 13 ago. 2018b.

BRASIL. Senado Federal. Projeto de Lei do Senado Federal $n^{\circ}$ 283/2012. 2012b. Disponível em: https://www25.senado.leg.br/ web/atividade/materias/-/materia/106773. Acesso em 12 jan. 2019.

BRASIL. Serasa Experian. Disponível em: https://www.serasaexperian.com.br/amplie-seus-conhecimentos/indicadores-economicos. Acesso em: 8 jan. 2019e.

BRASIL. Serviço de Proteção ao Crédito. Confederação Nacional de Dirigentes Lojistas (SPC/CNDL). Inadimplentes no Brasil 2017 Perfil e comportamento frente às dívidas. 2017. Disponível em: file://C:/Users/User/Downloads/Analise_perfil_inadimplente_2017.pdf. Acesso em: 8 jan. 2019.

BRASIL. Serviço de Proteção ao Crédito - SPC Brasil. Disponível em: https://www.spcbrasil.org.br/pesquisas/indice/4890. Acesso em: 15 ago. 2018c.

BRASIL. Serviço de Proteção ao Crédito - SPC Brasil. Disponível em: https://www.spcbrasil.org.br/pesquisas/indice/5047. Acesso em: 14 ago. $2018 \mathrm{~d}$.

BULOS, Uadi Lammêgo. Curso de Direito constitucional. 11. ed. São Paulo: Saraiva, 2018.

CASTRO, Alexandre Samy de. Ensaio Sobre o Poder Judiciário no Brasil. 2012. 121 f. Tese (Doutorado) - Curso de Economia, Escola de Pós Graduação em Economia, Fundação Getúlio Vargas, Rio de Janeiro, 2012. Disponível em: http://bibliotecadigital. fgv.br/dspace/bitstream/handle/10438/11239/TESE_SAMY_2013.pdf?sequence=1\&isAllowed=y. Acesso em: 7 dez 2018.

CNJ. Conselho Nacional de Justiça. 2018. Disponível em: https://www.cnj.jus.br/wp-content/uploads/2011/02/8d9faee7812d35a58cee3d92d2df2f25.pdf25.pdf. Acesso em: 13 maio 2020.

EFRAT, Rafael. Global Trends in Personal Bankruptcy. American Bankruptcy Law Journal, vol. 76, 2002, p. 81-109.

HOBSBAWM, Eric John. A era do capital. 4. ed. Rio de Janeiro, Editora Paz e Terra S/A, 1988.

IBGE. Instituto Brasileiro de Geografia e Estatística. Analfabetismo cai em 2017, mas segue acima da meta para 2015.2018. Disponível em: https://agenciadenoticias.ibge.gov.br/agencia-noticias/2012-agencia-de-noticias/noticias/21255-analfabetismo-cai-em-2017-mas-segue-acima-da-meta-para-2015.html. Acesso em: 14 ago. 2018

MARQUES, Cláudia Lima; CAVALLAZZI, Rosângela Lunardelli (coord.). Direitos do consumidor endividado: superendividamento e crédito. São Paulo: Revista dos Tribunais, 2006. 400 p.

MARQUES, Claudia Lima; LIMA, Clarissa Costa; BERTONCELLO, Káren. Prevenção e tratamento do superendividamento: caderno de investigações científicas. Brasília: DPDC/SDE, 2010.

MARQUESI, Roberto Wagner; SABO, Isabela Cristina; LÊDO, Ana Paula Ruiz Silveira. A necessidade do diálogo das fontes nas relações de consumo suscetíveis ao comércio eletrônico. Quaestio luris, Rio de Janeiro, v. 11, n. 2, p.757-775, 2018.

NETO, Mario Furlaneto; BEZEN, Gabriela Cristina. O Direito fundamental de proteção ao consumidor em tempos de globalização e o fenômeno do superendividamento. Quaestio luris, Rio de Janeiro, v. 10, n. 4, p. b2.824-2.843, 2017.

PALHARES, Cinara. A tutela do consumidor excessivamente endividado como forma de preservação dos direitos fundamentais da pessoa humana. 2010. 277f. Dissertação (Mestrado) - Curso de Direito, Universidade de São Paulo, São Paulo, 2010.

PAULA, Ana Cristina Alves de. A Extensão do instituto da falência à pessoa natural enquanto mecanismo de tutela do consumidor superendividado. Revista Brasileira de Direito Empresarial, Florianópolis, v. 2, n. 1, p. 94-114, maio 2016.

PELLEGRINO, Fabiana Andréa de Almeida Oliveira. A tutela em face do superendividamento na perspectiva da uma hermenêutica contemporânea das relações de consumo. 2014. 272f. Dissertação (Mestrado) - Universidade Federal da Bahia, Programa de Pós-Graduação em Direito, Mestrado em Direito Público, Salvador, 2014.

PORTO, Antonio Augusto Cruz; TORRES, Cibele Merlin. Entropia orçamentária: o papel das instituições financeiras na viabilização do crédito familiar sustentável. Revista Direito e Liberdade. Natal, v. 15, n. 3, p. 11-30, set./dez. 2013. 